\title{
Quarterly Environmental Radiological Survey Summary \\ First Quarter 1997 100, 200, 300, and 600 Areas
}

S. M. McKinney

B. M. Markes

Rust Federal Services Northwest

Date Published

April 1997

Prepared for the U.S. Department of Energy

Assistant Secretary for Environmental Management

Project Hanford Management Contractor for the

U.S. Department of Energy under Contract DE-AC06-96RL 13200

Approved for public release; distribution is unlimited. 


\section{RELEASE AUTHORIZATION}

Document Number: HNF-SP-0665-24

Document Title: Quarterly Environmental Radiological Survey Summary

First Quarter $1997100,200,300$, and 600 Areas

Release Date: $\quad 4 / 23 / 97$

This document was reviewed following the procedures described in WHC-CM-3-4 and is:

APPROVED FOR PUBLIC RELEASE

WHC Information Release Administration Specialist:

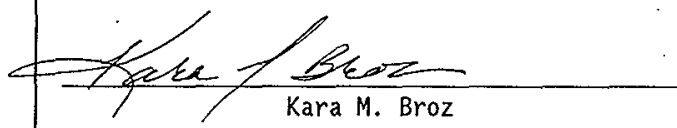

Apri1 23, 1997 


\section{APPROVAL PAGE}

PREPARED BY

REVIEWED BY

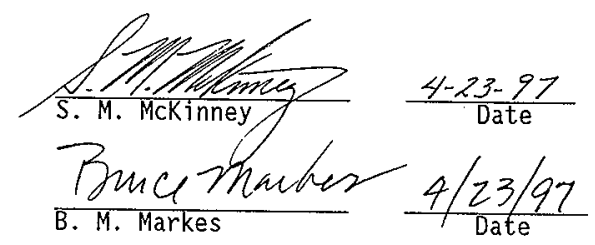

APPROVED BY:

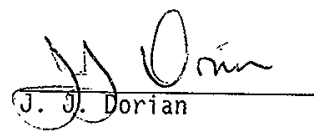

Q4.23.9Z

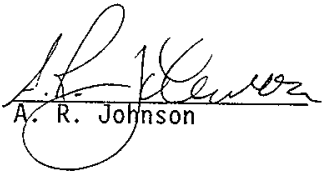

$\frac{4 / 23 / 97}{\text { Date }}$ 


\section{EXECUTIVE SUMMARY}

This report provides a summary of the radiological surveys performed in support of near-facility environmental monitoring at the Hanford Site. The First Quarter 1997 survey results and the status of actions required are summarized below:

- All of the routine environmental radiological surveys scheduled during January, February, and March 1997, were performed as planned.

- One hundred four environmental radiological surveys were performed during the first quarter 1997, twenty-nine at the active waste sites and seventy-five at the inactive waste sites. Contamination above background levels was found at eight of the active waste sites and seven of the inactive waste sites. Contamination levels as high as $>1,000,000$ disintegrations per minute (dpm) were reported. of these contaminated surveys twelve were in Underground Radioactive Material (URM) areas and three were in contamination areas. The contamination found within ten of the URM areas was immediately cleaned up and no further action was required. In the remaining five sites the areas were posted and will require decontamination. Radiological Problem Reports (RPR's) were issued and the sites were turned over to the landlord for further action if required.

- During the first quarter of 1997, 5.6 hectares (13.8 acres) were stabilized and radiologicaliy down posted from Contamination Area (CA)/Soil Contamination (SC) to URM.

- During the first quarter of 1997, the size of 216-A-25 Gable Mountain Pond was increased from 30.4 to 34.5 hectares $(75.0$ to 85.2 acres). This increase in size was due to the correction of the original boundary area by using the advanced technology of a global positioning system (GPS).

An area, 1.6 hectares ( 4.0 acres), east of and adjacent to the 241-S/SX/SY tank farm complex was posted as a contamination/soil contamination area.

- Five open Surveillance Compliance Inspection Reports (SCIRs) had not been resolved.

Responsibilities for the unresolved SCIRs are as follows:

\section{LANDLORD}

Tank Farm Operations (TFO)

Solid Waste Operations (SW0)

\section{OPEN SCIR/CAR}




\section{TOP TEN PRIORITY RANKING}

Below is a listing of the top ten waste sites in order of highest priority ranking for contamination control. The waste site may have an open SCIR or CAR identifying the contamination. An explanation of the prioritization system is on page 13 of this report.

\section{SITE}

1. 241-C Tank Farm Perimeters

2. 241-B Tank Farm Perimeters

3. 241-BX-BY Tank Farm Perimeters

4. 241-S, SX, SY Tank Farm Perimeters

5. UN-216-E-6 241-BX-155 Diversion BoX

6. UN-216-W-35 207-U Retention Basin

7. 216-B-64 Basin

8. 207-A Retention Basin

9. 207-B Retention Basin

10. 241-AP Tank Farm
CUSTODIAN

TFO

TFO

TFO

TFO

TFO

ERC

B-Plant

TFO

B-Plant

TFO
$\mathrm{SCIR} / \mathrm{CAR}$

9008EP200-068

8909EP200-036

9007EP200-056

9208ERI-006

NONE

NONE

NONE

NONE

NONE

NONE 
TOP TEN PRIORITY RANKING ......................

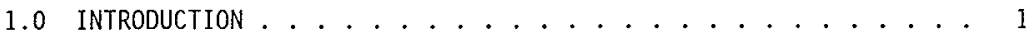

AREA RADIOLOGICAL CONTAMINATION ILLUSTRATIONS ... 2-11

TABLE 1 , OPEN SCIRS AND CARS ............ 12

2.0 PROGRAM DESCRIPTION ....................... 13

2.1 ENVIRONMENTAL RADIOLOGICAL SURVEY PROGRAM OBJECTIVES $\ldots 13$

2.2 PRIORITY RANKING SYSTEM ............... 13

2.3 ENVIRONMENTAL STANDARDS ............... 14

2.4 SURVEY METHODS AND PROCEDURES . . . . . . . . . . . 16

2.4 .1 ROAD/RAILROAD SURVEYS . . . . . . . . . . 16

2.4.2 WASTE SITES AND OTHER RADIOLOGICAL AREA SURVEYS . . 16

3.0 RADIOLOGICAL SURVEY RESULTS . . . . . . . . . . . . 17

3.1 ENVIRONMENTAL RADIOLOGICAL SURVEY SUMMARY . . . . . . . . . 17

TABLE 2, 1996 CONTAMINATION SAMPLES . . . . . . . . 21

3.2 COMPLIANCE/SURVEILLANCE REPORTS CLOSED . . . . . . 20

3.3 STATUS OF OPEN SURVEILLANCE AND COMPLIANCE REPORTS . . . 20

4.0 SUMMARY $\ldots \ldots . \ldots . \ldots . \ldots . \ldots . \ldots . \ldots$

TABLE 3 , OUTDOOR CONTAMINATION STATUS . . . . . . . 22 


\subsection{INTRODUCTION}

Routine radiological surveys are part of near-facility environmental monitoring which monitors and helps direct the reduction of the radiological areas at the Hanford Site. The routine radiological surveys are performed by the Southern Area Remediation Support Group and the Site Support Services Radiological Control Group as directed by Environmental Monitoring and Investigations. The surveys included in this program consist of inactive waste sites; outdoor radiological control areas; tank farm perimeters and associated diversion boxes, 1 ift stations, and vent stations; perimeters of active or uncovered waste sites such as burial grounds, retention basins, ponds, process trenches, and ditches; underground pipelines; and road and rail surfaces (Figures 1 through 10). This report provides a summary of the radiological surveys performed during the First Quarter of 1997. The status of corrective actions required from current and past reports are also discussed.

A waste site survey schedule, WHC-SP-0098-8, was developed by Environmental Monitoring and Investigations and reviewed by the Southern Area Remediation Support Group and the Site Support Services Radiologica? control Group. Environmental Monitoring and Investigations reviews the radiological survey reports and files a copy for historical purposes and reference. Radiological conditions are tracked and trends noted. All sites are surveyed at least once each year. The survey frequencies for particular sites are based on site history, radiological conditions, and general maintenance. Special surveys may be conducted at irregular frequencies if conditions warrant (e.g., growth of deep-rooted vegetation is noted at a waste site). Radiological surveys are conducted to detect surface contamination and document changes in vegetation growth, biological intrusion, erosion, and general site maintenance conditions. Survey data are compared with standards identified in WHC-CM-7-5, Environmental Compliance, as well as previous surveys to recognize possible trends, assess environmental impacts, and help determine where corrective actions are needed.

Landlords of the sites found out of compliance may be issued a Radiological Problem Report (RPR) from the appropriate radiological Control Groups. Open SCIRs and CARs are Tisted in Table 1 of this report.

The surveys scheduled for this program consist of inactive waste sites; outdoor radiological areas; tank farm perimeters and associated diversion boxes, lift stations, and vent stations; perimeters of active or uncovered waste sites such as burial grounds, retention basins, ponds, process trenches, and ditches; underground pipelines; and road and rail surfaces. Surveiliance of the active nuclear facilities and inside the tank farms is the responsibility of the facility. These radiological surveys are to determine surface radiological conditions and do not constitute a release survey. Therefore, surveys that detect no contamination in radiological areas do not release the site from control but may result in a posting status change. 


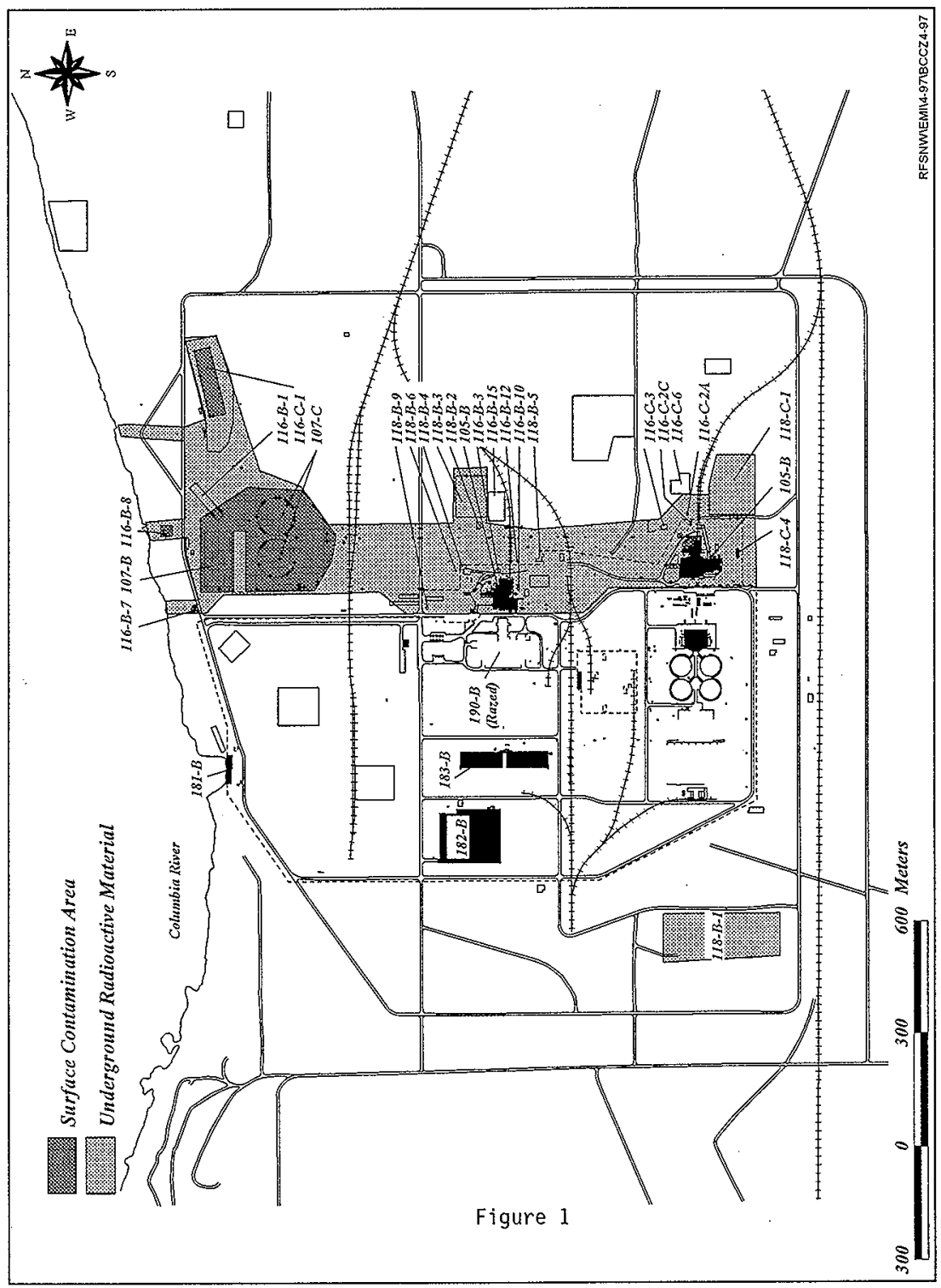




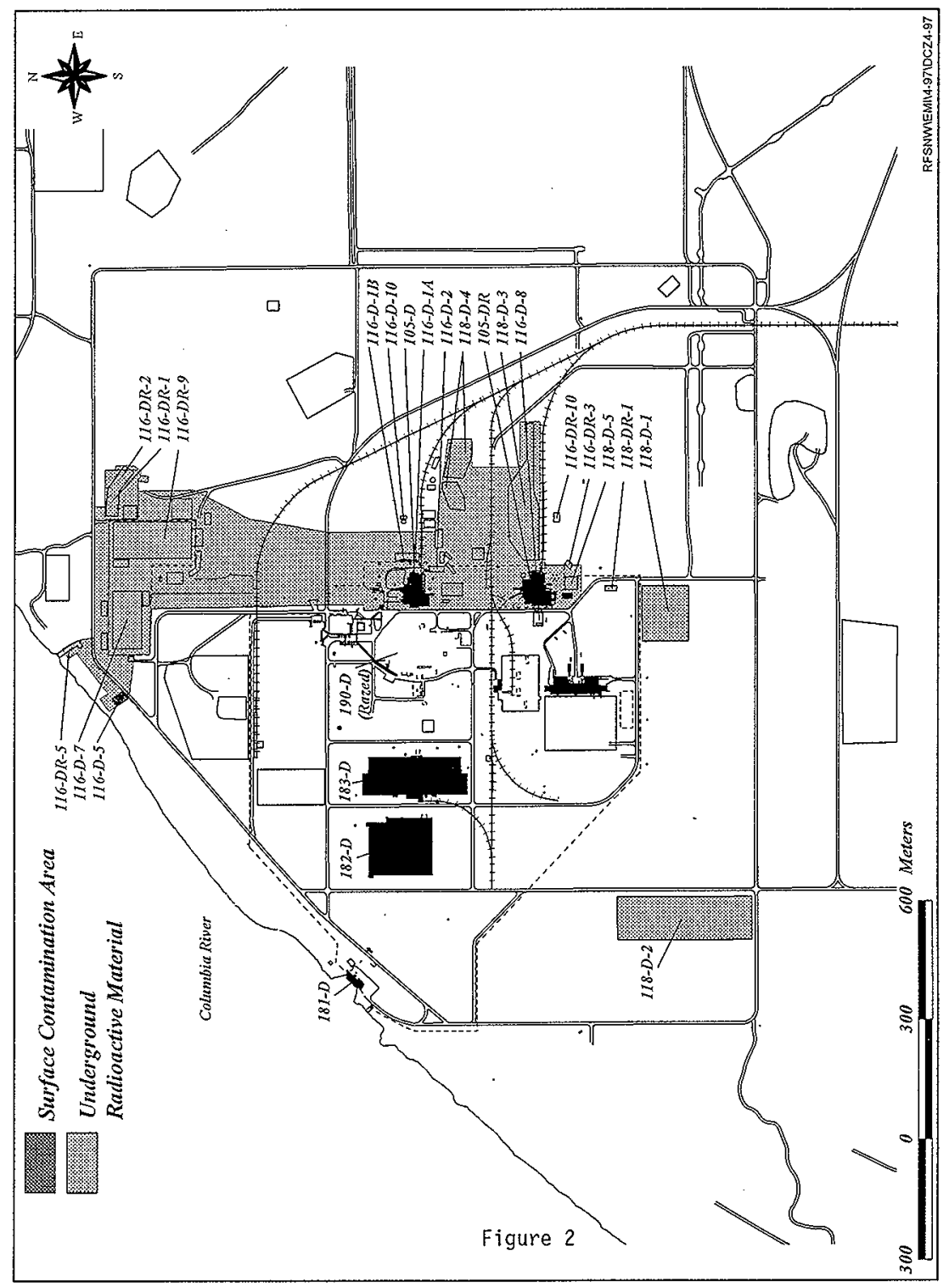




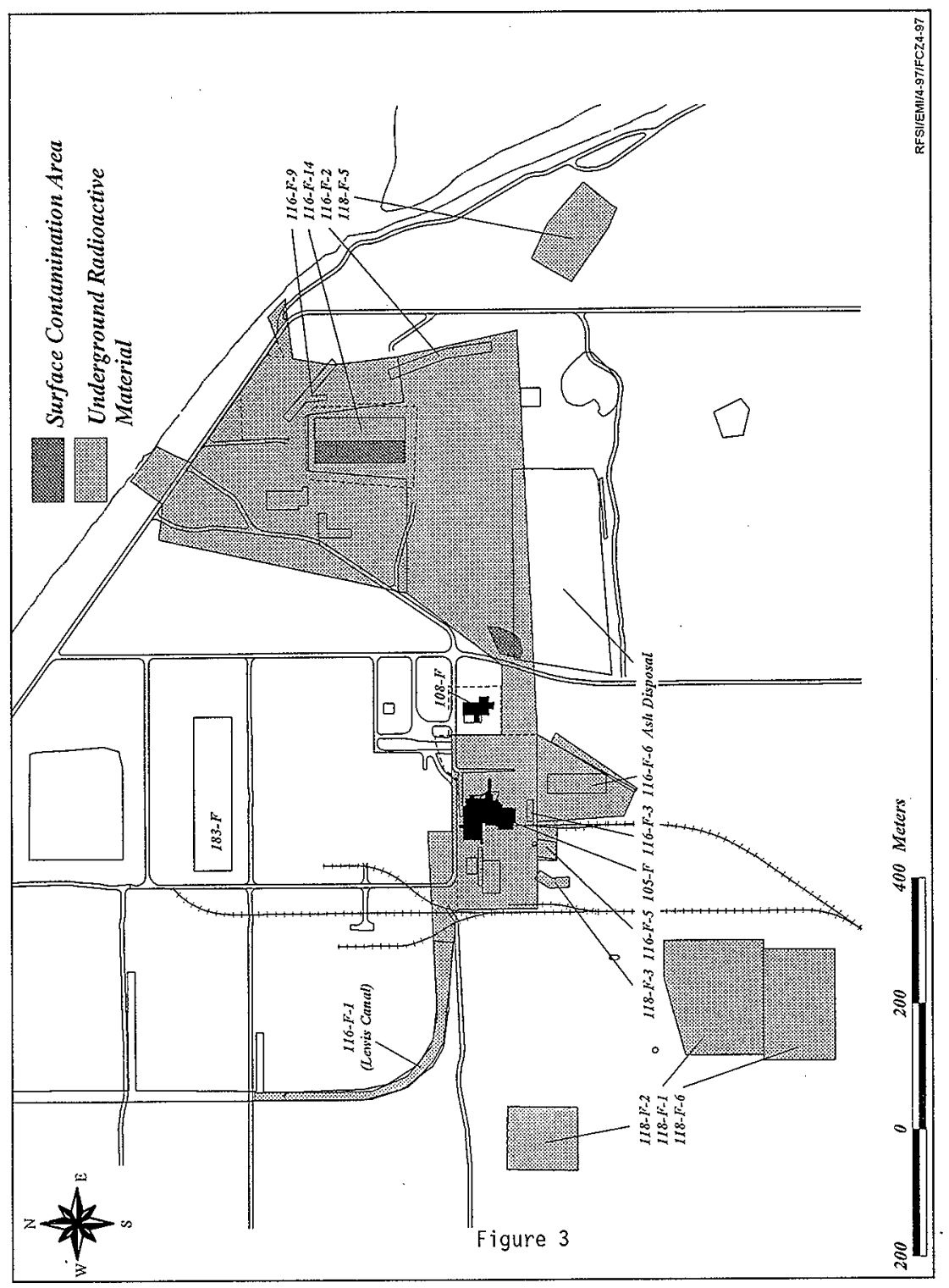




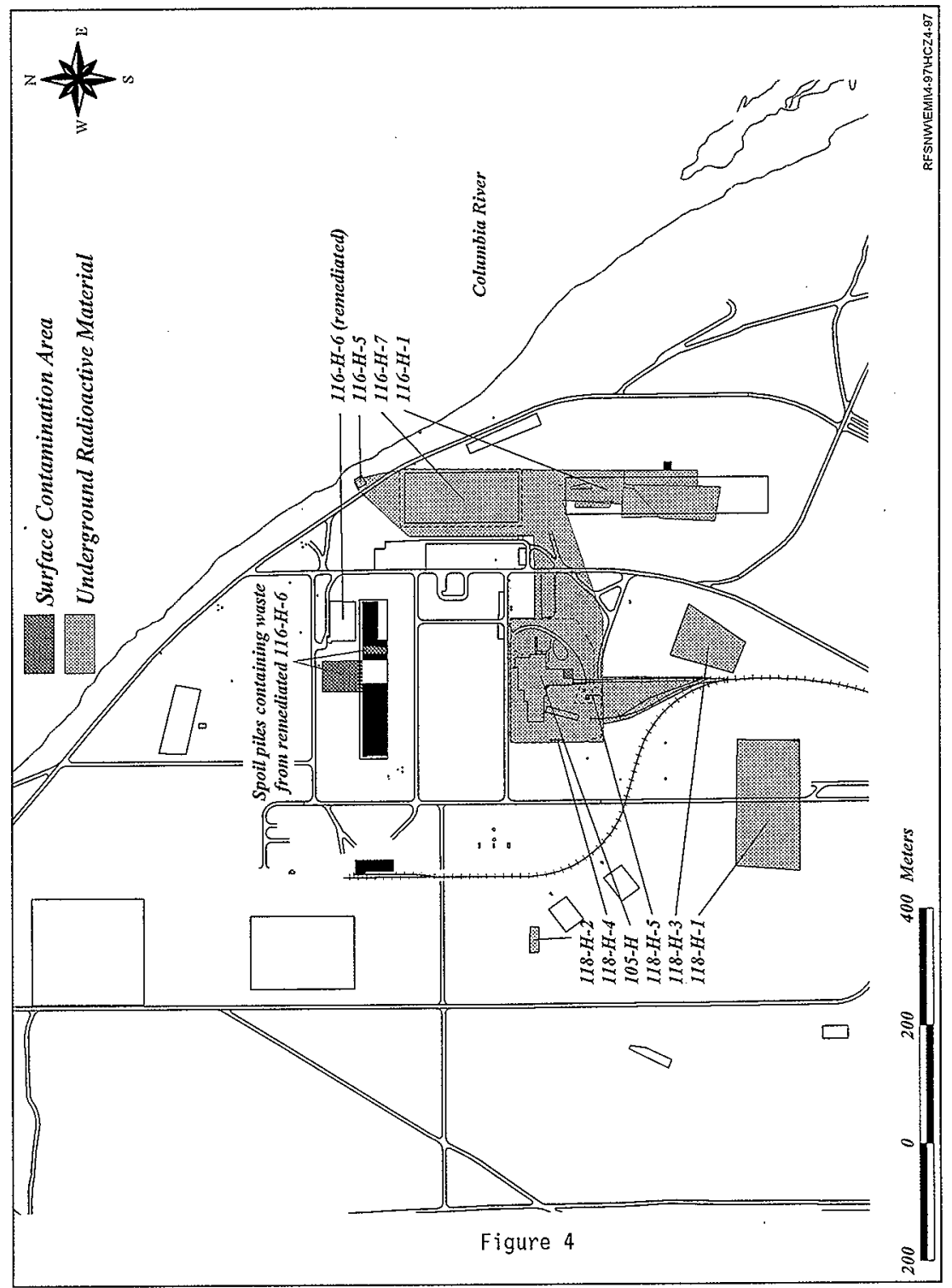




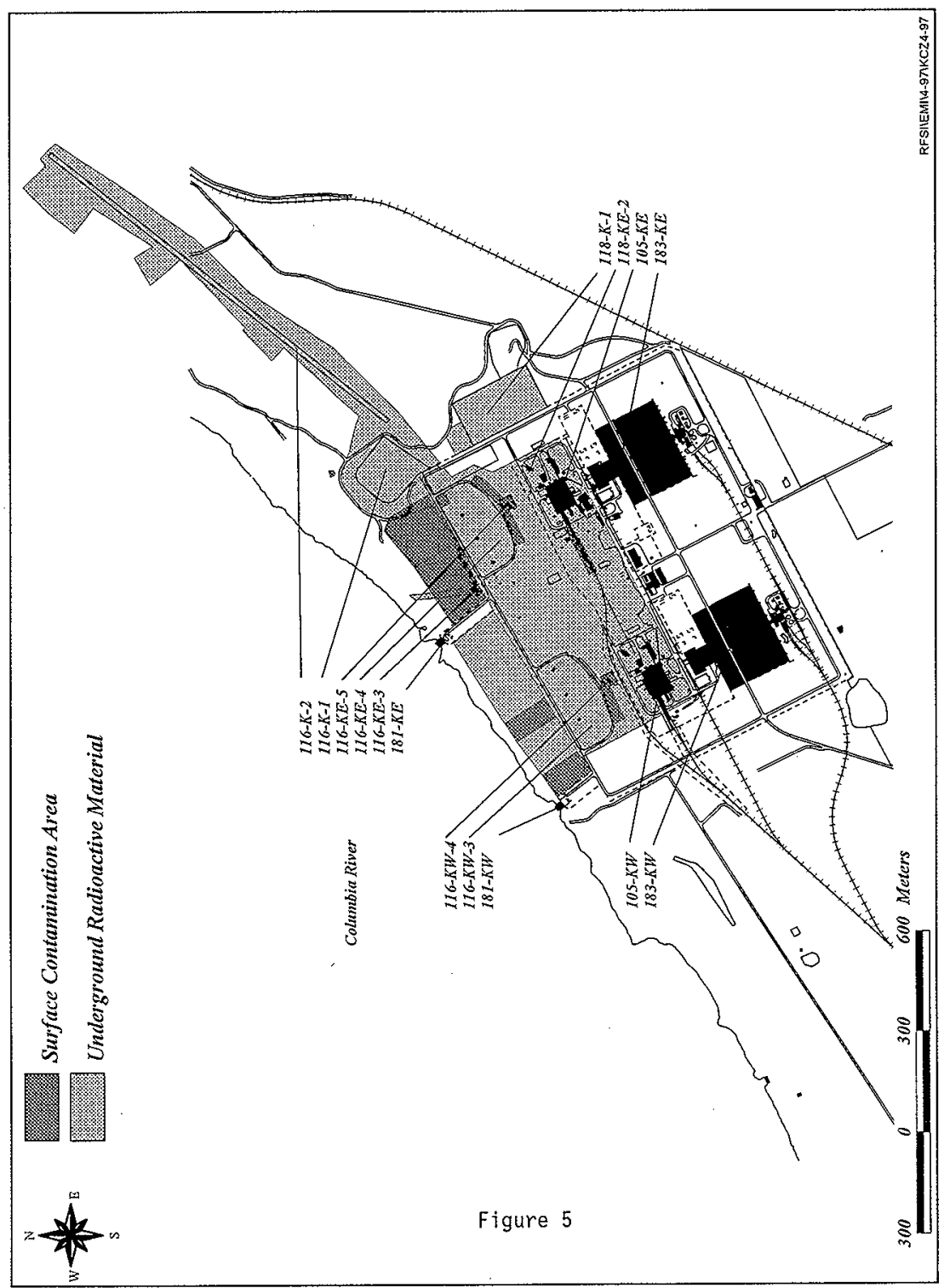




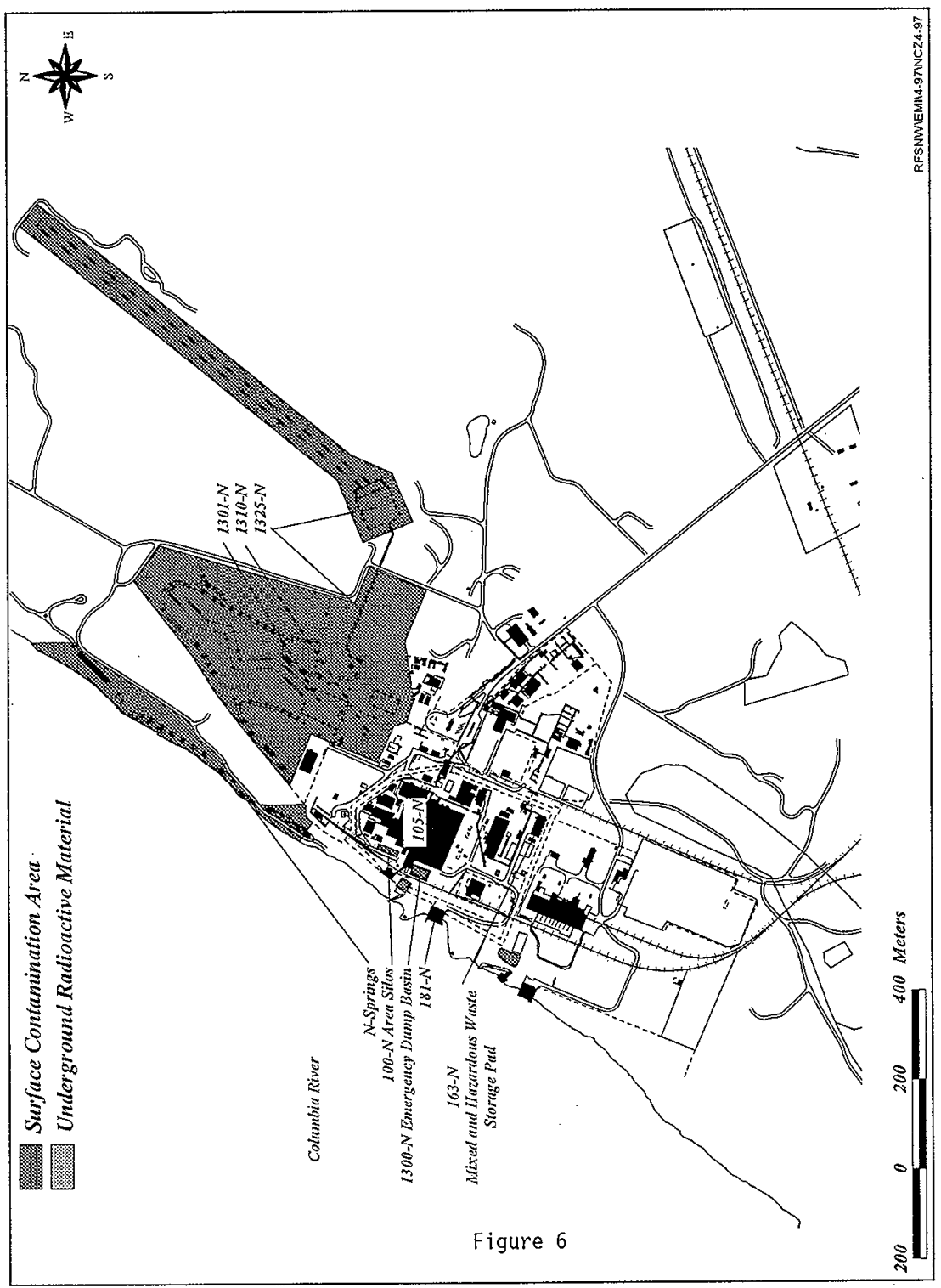




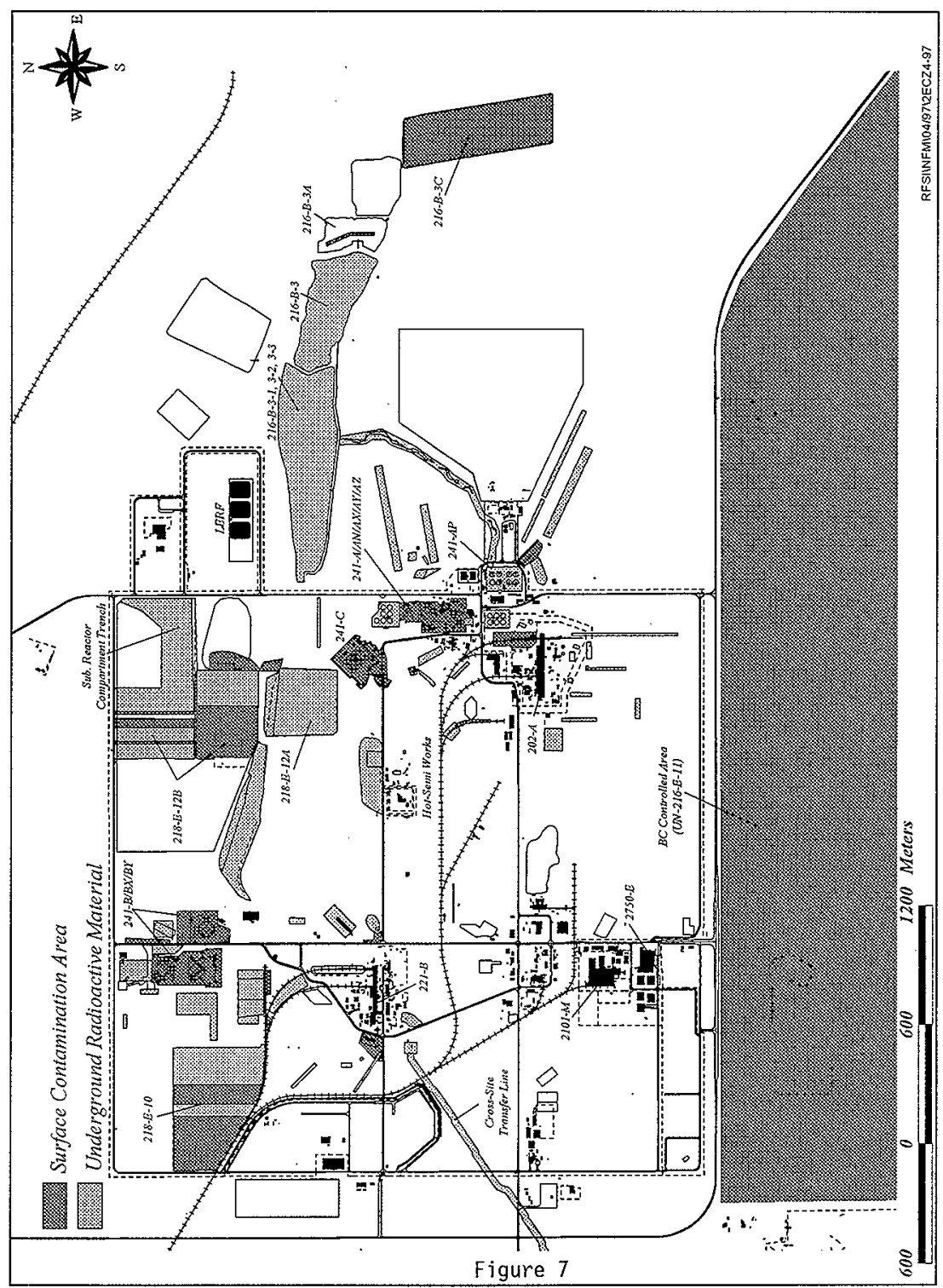




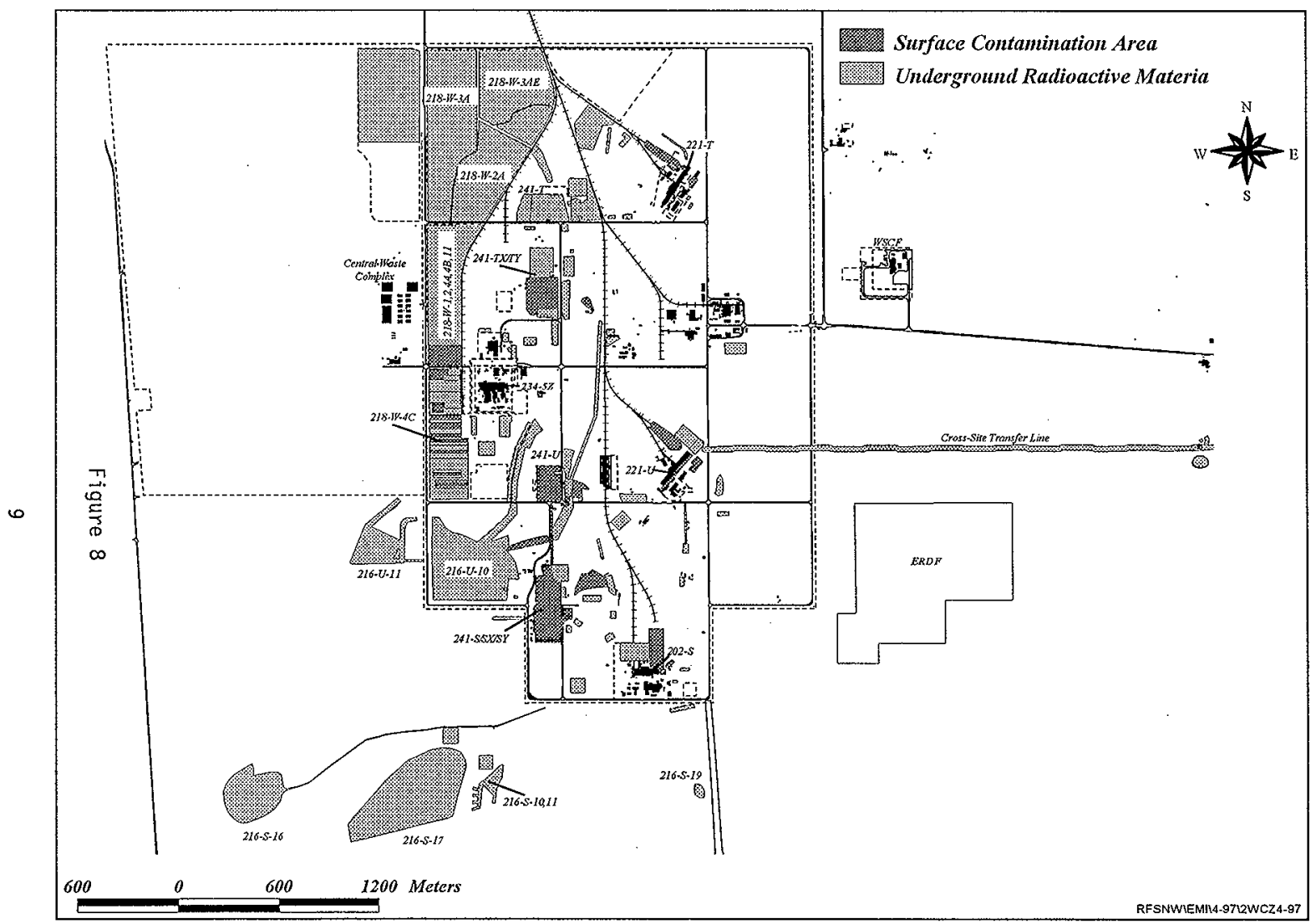




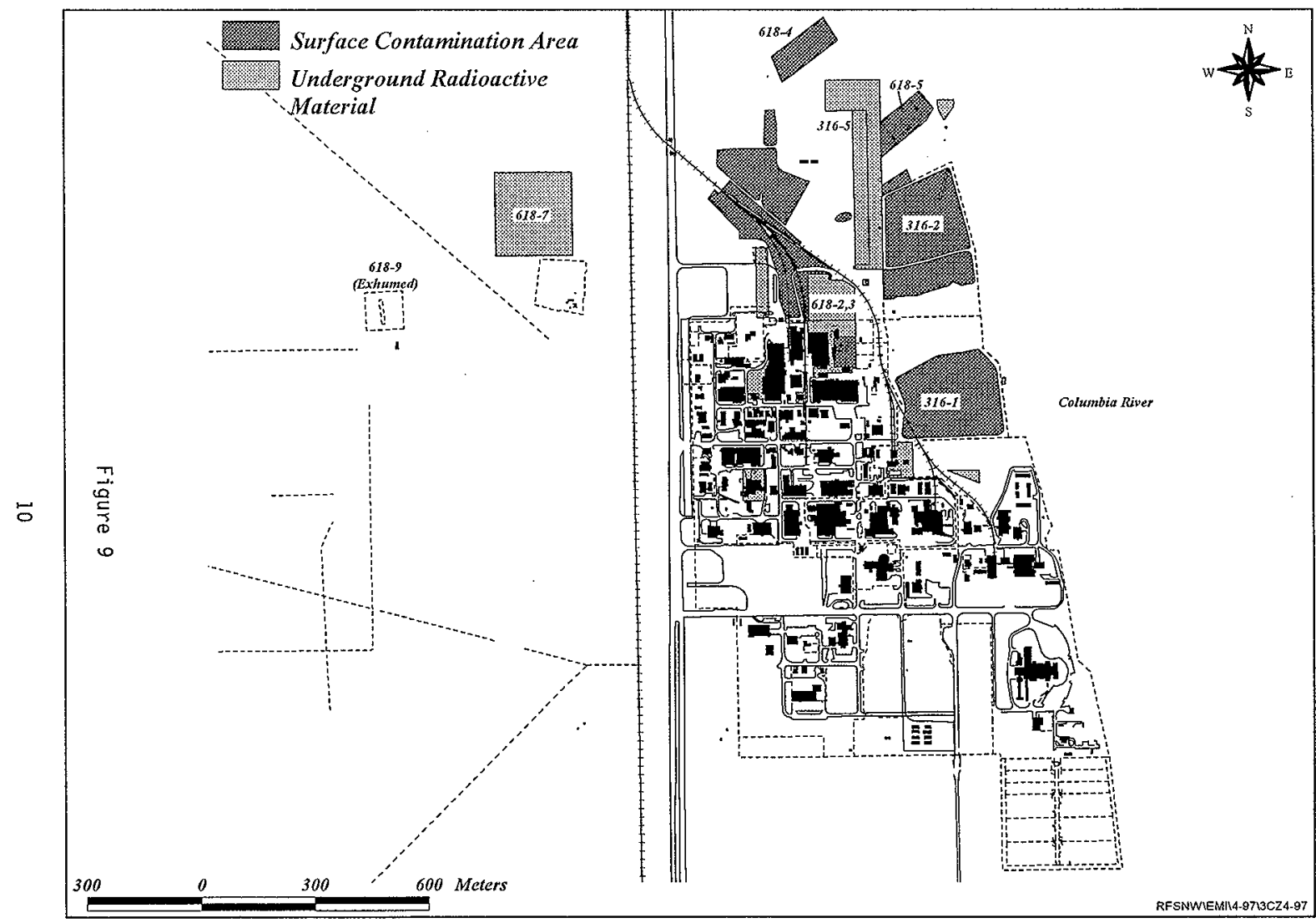




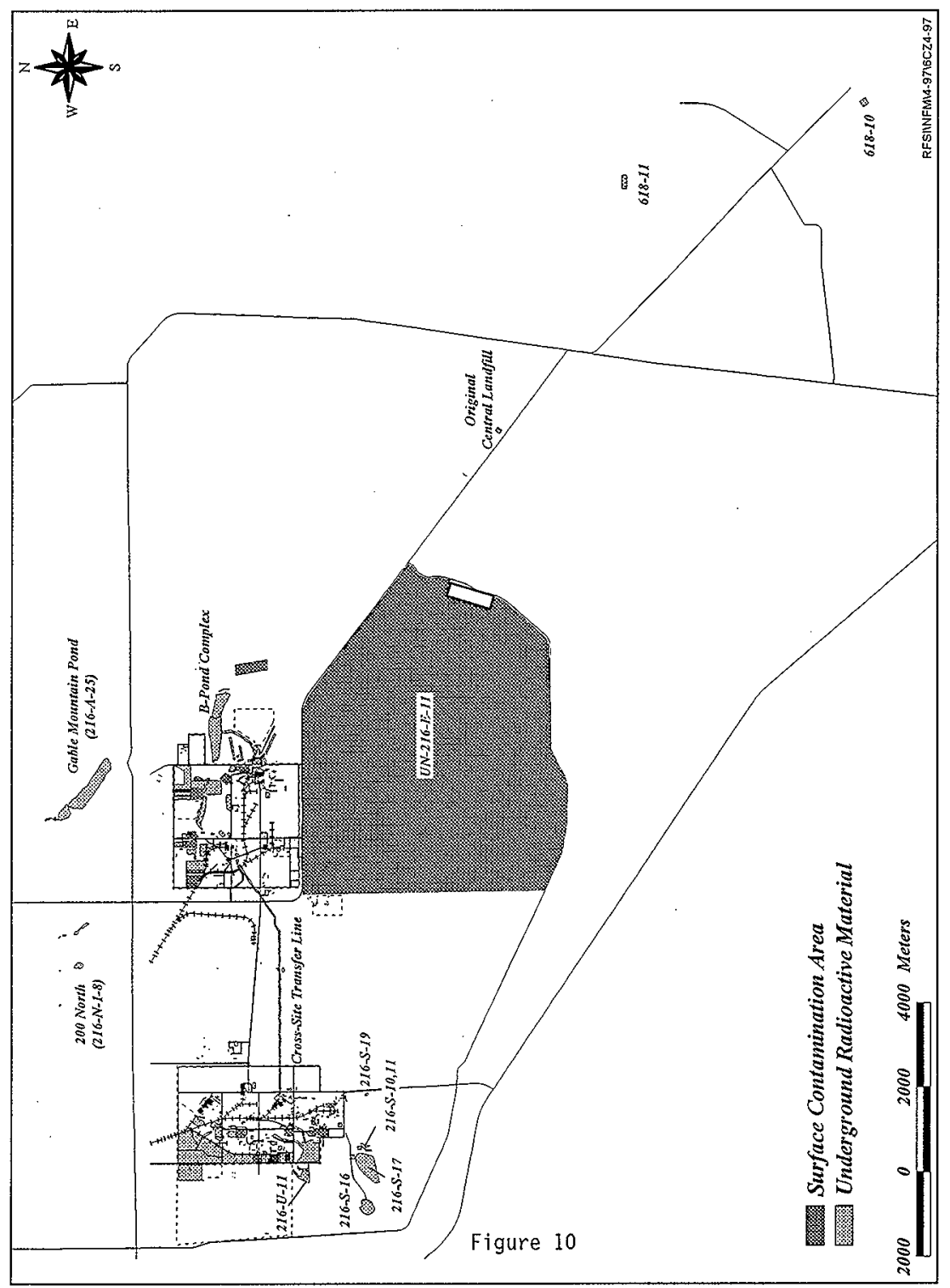


Table 1. Open SCIRs AND CARs

(maximum 15 points)

\begin{tabular}{|c|c|c|c|c|c|c|}
\hline SCIR/CAR & SITE & $\begin{array}{c}\text { DATE } \\
\text { INITIATED }\end{array}$ & $\begin{array}{c}\text { MONTHS } \\
\text { OPEN }\end{array}$ & ECD & $\begin{array}{c}\text { SITE } \\
\text { RANKING } \\
\end{array}$ & CUSTODIAN \\
\hline 8909EP200-036 & 241-B FARM PERIMETERS & $09 / 01 / 89$ & 99 & $09 / 30 / 97$ & 13 & TFO \\
\hline 9007EP200-056 & BX-BY TANK FARM PERIMETERS & $07 / 20 / 90$ & 88 & $09 / 30 / 97$ & 13 & TFO \\
\hline 9008EP200-068 & C-TANK FARM PERIMETERS & $08 / 13 / 90$ & 87 & $09 / 30 / 97$ & 13 & TFO \\
\hline 9208ERI -006 & 241-S, SX, SY TANK FARM PERIMETERS & $08 / 14 / 92$ & 63 & $09 / 30 / 97$ & 12 & TFO \\
\hline $9607 N F M-003$ & $\begin{array}{l}\text { 218-E-10, 218-E-12B, 218-W-3A, AND } \\
218-W-4 C \text { BURIAL GROUNDS }\end{array}$ & $07 / 18 / 96$ & 8 & $04 / 31 / 96$ & & \\
\hline
\end{tabular}




\subsection{PROGRAM DESCRIPTION}

\subsection{ENVIRONMENTAL RADIOLOGICAL SURVEY PROGRAM OBJECTIVES}

Environmental radiological surveys are performed to:

- Identify priorities for environmental cleanup or stabilization of surface contamination.

- Determine compliance with Department of Energy requirements and applicable policies and standards regarding operational control and environmental and radiological protection.

- Identify trends in radioactive contamination levels and contamination migration at waste sites and other radiological areas.

- Assess the surface integrity of solid and liquid waste disposal sites.

- Monitor for unplanned releases of radioactivity to the operations area environment.

\subsection{PRIORITY RANKING SYSTEM}

A numerical ranking system is used for sorting contaminated waste sites relative to environmental radiological concerns. This system provides a priority guideline to responsible landlords for clean-up or stabilization of surface-contaminated areas.

A numerical value is assigned based on the level of contamination, site accessibility, and contamination mobility. Site histories are examined by reviewing past and present radiological surveys. Contamination levels from 1,000 counts per minute (cpm) to greater than $10 \mathrm{mrad} / \mathrm{hr}$ (as measured on Radiological Control's field survey instruments) are considered and assigned a numerical value of 1 (lowest value) to 5 (greatest value). Any removable alpha contamination will be considered a high priority and will receive a contamination value of 5 . Location is evaluated for accessibility. A restricted area would receive the lowest point value of 1 progressing up to a value of 5 where the public could have access. Mobility refers to contamination that can be or has a history of being transported from where it was originaliy identified to places outside of the posted radiological area, Fixed contamination would receive a value of 1 progressing to contamination that is blown by the wind or the result of biological uptake receiving a value of 5 . There is a maximum of 15 points possible for this ranking system.

It should be noted that this system is not intended to be a total risk assessment, but rather a way of communicating environmental significance to the 1 andlords and their program offices. Other elements of the site clean-up process are considered such as costs, location, political emphasis and engineering strategies before a site is actually remediated. 


\subsection{ENVIRONMENTAL. STANDARDS}

Radiological survey data are used to determine compliance of Radioactive Waste Sites with WHC-CM-7-5, Environmental Compliance, Section 6.0 (Rev. 1) and BHI-EE-02, Environmental Requirements, Section 7.0 (Rev. 0), requirements.

Applicable requirements include the following:

1. Engineered barriers shall be provided, where applicable, over the disposal site to inhibit radionuclide transport to the surface.

2. Inactive waste site boundaries shall be accurately and permanently marked with Hanford plant standard (AC-5-40) approved concrete marker posts. Sites never used and those that are no longer contaminated do not require marker posts.

3. Facility effluent lines which are potential discharge points shall be isolated, capped, or sealed off to prevent accidental releases to inactive sites. This shall be verified and documented.

4. Active and inactive waste sites shall be inspected and surveyed at least annually.

5. One or more of the following actions shall be taken when contamination of any type is detected (either new or in excess of action limits) to prevent the migration or mobilization of the contamination:

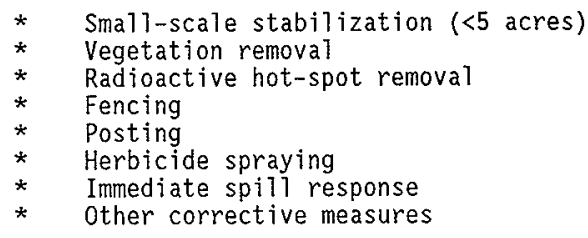

6. Information regarding all suspect waste sites or newly identified waste sites shall be provided for documentation into the Environmental Sites Database/Waste Identification Data System (ESD/WIDS).

7. Inactive waste sites shal1 be maintained to control deep-rooted vegetation that could provide transport of contamination to the surface through plant uptake. The application of herbicides or pesticides may be required. 
Environmental Monitoring and Investigations is responsible for:

1. Establishing radiological survey schedules of active and inactive radiological waste sites.

2. Conducting inspections of active and inactive waste sites to determine compliance with the physical and radiological requirements.

3. Compiling and maintaining copies of historical records, including radiological survey reports, compliance assessment reports (CARs), surveillance/compliance inspection reports (SCIRS), and other information for each active and inactive radioactive waste site.

4. Trending radiological data, and issuing reports on the status of radiological surveys and compliance assessments for active and inactive radioactive waste sites.

5. Reviewing any proposed activity, other than routine inspections, that may impact or may be impacted by any active and inactive waste site.

The above mentioned requirements apply to all active and inactive radioactive waste sites which include cribs, trenches, ditches, ponds, French drains, underground pipelines, burial grounds and other areas of concern such as the perimeters of tank farms and active burial grounds, and radioactive contamination due to spills or releases. Interiors of tank farms, active burial trenches and radiological areas where operations are ongoing are not included, because monitoring and tracking is done by the facility operations and other requirements are applicable to these areas.

In order to compare standards [as established in WHC-CM-7-5, Section 6.0] and field instrument values, a conversion factor is necessary. This conversion factor has been established where $20,000 \mathrm{dpm}(2,000 \mathrm{cpm})$ are approximately equivalent to one millirem per hour for beta-emitting radionuclides. It must be understood that converting field instrument values, which include both beta and gamma energies, is approximate and does not allow for absolute precision. 


\subsection{SURVEY METHODS AND PROCEDURES}

Surveys documented by this report include road/railroad surfaces, cribs, underground pipelines, stabilized burial grounds, covered ponds and ditches, tank farm perimeters, active burial ground perimeters, unplanned release sites and other radiological areas. Methods and procedures for these surveys can be found in WHC-CM-7-4, Operational Environmental Monitoring; HSRCM-1, Hanford Site Radiological Control Manual; and WHCIP-0718, Health Physics Technical Practices and Procedures.

\subsubsection{ROAD/RAILROAD SURVEYS}

Road and Railroad Surveys are conducted with a vehicle equipped with "high railers", which allows the vehicle to travel both on the roads or railroads, and sodium iodide detectors. The detector height is adjustable and the average survey height is six inches.

The vehicle is driven at less than five miles per hour. If activity above background is detected, the vehicle is stopped and a thorough survey is made with a portable count rate meter equipped with a pancake type probe to identify the extent of the contamination. Appropriate management is notified if road/railroad contamination is identified, and corrective actions are initiated.

\subsubsection{WASTE SITES AND OTHER RADIOLOGICAL AREA SURVEYS}

Surveys at waste sites and other radiological areas may be conducted with vehicles equipped with radiation detection instruments or with portable field instruments. Field instrument survey results are reported in disintegrations per minute (using a correction factor of $10 \mathrm{dpm} / \mathrm{cpm}$ ) as detected by using a Geiger-Mueller detector for beta/gamma radiation equipped with a pancake type probe. Alpha survey results are reported in disintegrations per minute (using a correction factor of $7 \mathrm{dpm} / \mathrm{cpm}$ ) as measured with a portable alpha meter (PAM). Surveys include the perimeter and portions of the ground surface of radiological areas. Wherever possible, smear surveys are made on the surface of exposed equipment and other hard surfaces within a radiological area.

Vegetation, animal burrows, and animal feces are also monitored to detect biological transport. Detailed survey practices and procedures are described in WHC-CM-7-4, Operational Environmental Monitoring; HSRCM-1, Hanford Site Radiological Control Manual; and WHC-IP-0718, Health Physics Technical Practices and Procedures. 


\subsection{RADIOLOGICAL SURVEY RESULTS}

All the routine environmental radiological surveys scheduled during the first quarter of 1997, were completed with no exceptions.

Surveys of active and inactive waste disposal sites included cribs, trenches, burial grounds, covered ponds and covered ditches. The survey schedule for environmental sites is outlined in WHC-CM-7-4, Section 12, and in WHC-SP-0098-8, Rev. 0. Radiological surveys of the construction/remediation activities are performed by Environmental Restoration Contractor and are not included in this report.

One hundred four environmental radiological surveys were performed during the first quarter of 1997. Contamination above background Tevels was found at eight of the surveyed active waste site areas and seven of the inactive waste site areas. Contamination levels ranging from a low of 1,000 dpm to a high of $>1,000,000 \mathrm{dpm}$ were reported. Of the contamination found, twelve sites were located in URM areas and three sites were located in a CA/SCA areas.

The contamination found in ten of the URM areas was immediately cleaned up and no further action was required. The contamination found in the remaining URM five areas were posted and will require decontamination. Radiological Problem Reports were issued and the remaining sites were turned over to the landlord for further action.

The radiologically contaminated areas have been reposted to meet the new requirements as outl ined in the Hanford Site Radiological Control Manual, HSRCM-1. The posting includes Contamination, High Contamination (activity $>100,000 \mathrm{dpm} / 100 \mathrm{~cm}^{2} \mathrm{~B} / \mathrm{Y}$ and $\left./ 0 \mathrm{r}>10,000 \mathrm{dpm} / 100 \mathrm{~cm}^{2} \alpha\right)$, Soil Contamination, Underground Radioactive Materiat, Radiological Buffer, and Radiation/High Radiation Areas. For continuity between quarterly reports issued in 1996, the use of Surface Contamination (SC) areas in this report includes Contamination, High Contamination, and So 11 Contamination areas.

\subsection{RADIOLOGICAL SURVEY SUMMARY}

This report provides a synopsis of the radiological survey results conducted during first quarter of calendar year 1997. The stabilization efforts and release surveys for three waste sites resulted in the down posting from SC to URM or released of 5.6 hectares (13.8 acres).

During the first quarter, stabilization efforts and release surveys for the east portion of the 216-B-3C Pond, the contaminated portion of UN-216-W-24 (under the abandoned steam $]$ ine), and the 216-S-18 vehicle decontamination trench were completed and the sites were radiologically down posted from SC to URM or released.

During the first quarter of 1997 there were two radiological posted areas that increased in size. This increase resulted in an additional 4.1 hectares $(10.3 \mathrm{acres})$ of URM and 1.6 hectares $(4.0$ acres) of CA/SCA. The areas responsible for these increases were the 216-A-25 Gable Mountain Pond and the area east of the 241-S/SX/SY Tank Farm Complex. 
The primary reason for the increases in radiological posting is the advanced technology of the Global Positioning system (GPS) being used to determine the radiologically posted area boundaries.

While conducting radiological surveys, contaminated media was encountered and collected for analysis and/or disposal. Media found above actions levels defined in WHC-IP-0718, Health Physics Technical Practices and Procedures, are documented with a Radiological Problem Report and/or an Occurrence Report. The samples that are deemed appropriate are sent in for analysis (Table 2). The results of these analysis can be found in the Westinghouse Hanford Company Operational Environmental Monitoring Annual Report which is published in August of each year.

Abbreviations used in Table 2 are as follows:

NS - Not submitted for analysis.

NR - No activity recorded in the field.

$\angle D$ - Less than detectable with field instruments. 
둤

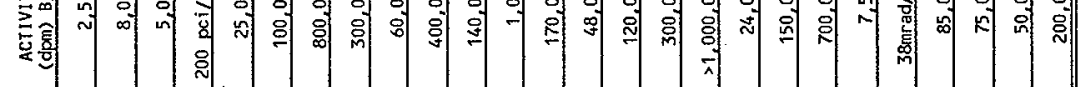

\begin{tabular}{|c|c|c|c|c|c|c|c|c|c|c|c|c|c|c|c|c|c|c|c|c|c|c|c|c|c|}
\hline 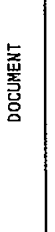 & $\begin{array}{l}5 \\
\vdots \\
\vdots \\
\vdots \\
\dot{\alpha}\end{array}$ & 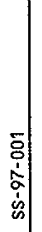 & $\begin{array}{c} \\
5 \\
5 \\
\vdots \\
\vdots \\
\vdots \\
0\end{array}$ & 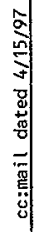 & 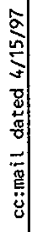 & 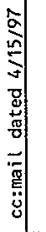 & 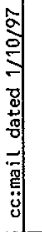 & \begin{tabular}{l|l}
$\tilde{8}$ \\
$\vdots$ \\
$\hat{\alpha}$ \\
$\vdots$ \\
0 \\
0
\end{tabular} & 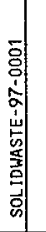 & 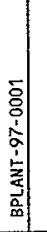 & 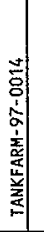 & 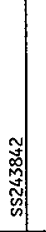 & 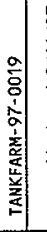 & 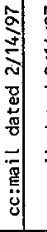 & 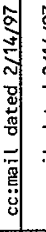 & 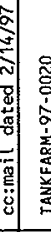 & 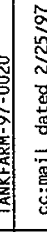 & 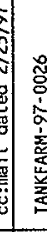 & 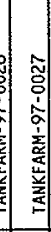 & 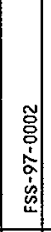 & 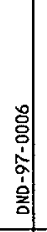 & 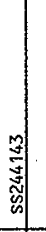 & 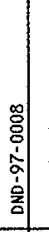 & 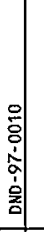 & 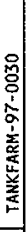 \\
\hline 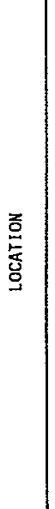 & 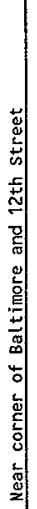 & 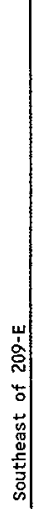 & 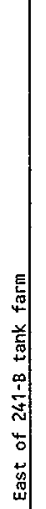 & 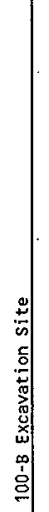 & 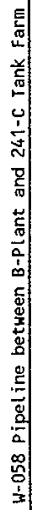 & 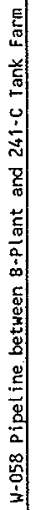 & 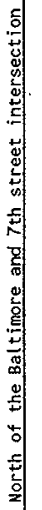 & 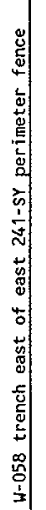 & 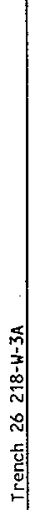 & 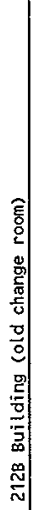 & 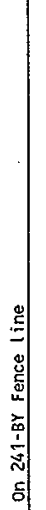 & 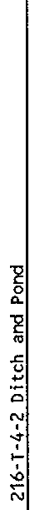 & 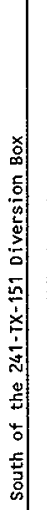 & 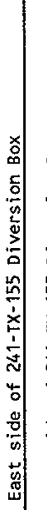 & 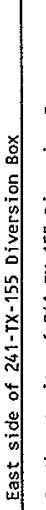 & 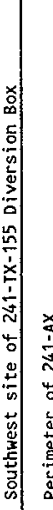 & 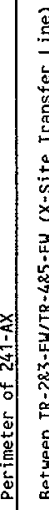 & 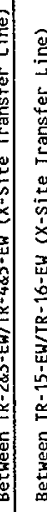 & 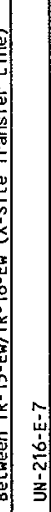 & 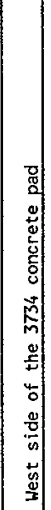 & 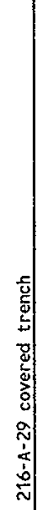 & 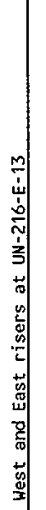 & 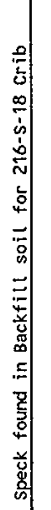 & 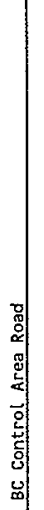 & $\begin{array}{l}\hat{1} \\
\underline{u} \\
0 \\
\hat{N} \\
\frac{1}{3} \\
z\end{array}$ \\
\hline 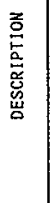 & 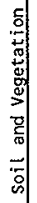 & 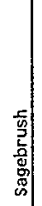 & 형 & ") & 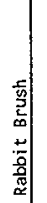 & $\overline{\mathrm{o}}$ & $\begin{array}{l}\text { 영 } \\
\text { oै } \\
\text { ô }\end{array}$ & 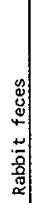 & 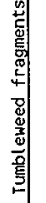 & 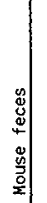 & 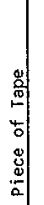 & 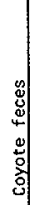 & 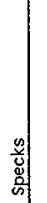 & 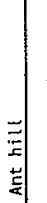 & 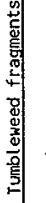 & & 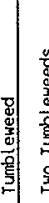 & | & $\begin{array}{l}\text { ․․에 } \\
\text { की }\end{array}$ & 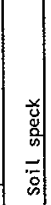 & $\begin{array}{l}\text { 总 } \\
\text { 。्ञ }\end{array}$ & $\begin{array}{l}n \\
\frac{n}{9} \\
\cdots \\
\alpha\end{array}$ & $\begin{array}{l}\text { :̆ } \\
\text { ตै山 }\end{array}$ & $\begin{array}{l}\text { की } \\
\text { o. } \\
\text { के }\end{array}$ & ") \\
\hline 嵩 & 웡 & 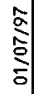 & 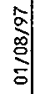 & 영 & $\begin{array}{l}0 \\
0 \\
0\end{array}$ & 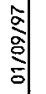 & 웡 & $\begin{array}{l}\text { a } \\
\vdots \\
\vdots \\
\vdots\end{array}$ & 휳 & 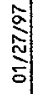 & $\begin{array}{l}\hat{a} \\
\text { ఫे } \\
\text { ồ }\end{array}$ & 웡 & à & 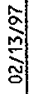 & 웡 & 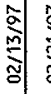 & స్- & â & 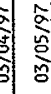 & $\begin{array}{l}\text { aे } \\
\text { 商 }\end{array}$ & $\stackrel{-}{=}$ & 웜 & aे & aे & 享 \\
\hline 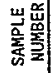 & 2 & $\stackrel{w}{x}$ & $\stackrel{0}{\approx}$ & 이 & 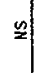 & 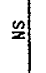 & $\approx$ & 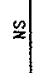 & $\cong$ & $\underline{z}$ & 2 & $\cong$ & $\cong$ & $\approx$ & $\approx$ & 2 & 웜 & $\boldsymbol{n}$ & $\stackrel{0}{z}$ & $\stackrel{2}{x}$ & $\cong$ & 2 & $\stackrel{n}{x}$ & $\underline{n}$ & $\stackrel{\varrho}{\approx}$ \\
\hline
\end{tabular}




\subsection{SURVEILLANCE/COMPLIANCE REPORTS CLOSED}

No SCIRs were closed during the first quarter of 1997.

\subsection{STATUS OF OPEN SURVEILLANCE AND COMPLIANCE REPORTS}

Five SCIRs, from past activities, remained open at the end of the first quarter of 1997. These reports are summarized on Table 1 to include the referenced site number, priority ranking points (maximum of 15 points based on contamination levels, location and mobility), responsible custodian, SCIR report number, and estimated completion date.

Abbreviations used on Table 1 include:

CAR - Compliance Assessment Report

SCIR - Surveillance/Compliance Inspection Report

ECD - Estimated Completion Date

ERC - Environmental Restoration Contractor

TFO - Tank Farm Operations

PTS - Points

TBD - To Be Determined 


\subsection{SUMMARY}

All the routine outdoor radiological surveys were completed during first quarter of calendar year 1997 in the 100, 200-East/West, 300 and 600 areas.

No SCIRs were closed (Section 3.2)

Five SCIRs remain open. Open reports have been addressed and clean-up plans with completion dates are being developed or are to be provided to Environmental Monitoring and Investigations.

\section{RADIOLOGICAL POSTING CHANGES}

An on going effort to stabilize and/or clean up areas of known contamination and to down post or release these areas from posting is being performed by the Environmental Restoration Contractor and by the facility managers. In the first quarter of 1997, 5.6 hectares (13.8 acres) were stabilized and down posted from CA/SC to URM. From the beginning of 1991 through the end of the first quarter of 1997, 4,012 hectares $(9,913$ acres) have been stabilized and down posted from CA/SC to URM or cleaned up and released. Table 3 shows the downward trend of the contamination status during this time period.

Radiological posting changes, by waste site, noted during the first quarter of calendar year of 1996 are as follows:

The remaining surface soil contaminated portion of UN-216-W-24, which was under the abandoned steam line, was scraped and placed into the 216-S-18 Vehicle Decontamination Trench and the trench was covered with clean soil. The area that was under the steam line was sampled and released and the decontamination trench was down posted from CA/SCA to URM, 0.4 hectares ( 1.0 acres).

The eastern portion of the 216-B-3C Pond was backfilled and down posted from CA/SCA to URM, 5.2 hectares (12.9 acres).

A GPS survey of the 216-A-25 Gable Mountain Pond boundaries resulted in the increase from 30.4 hectares $(75.0$ acres) to 34.5 hectares (85.2 acres) of URM.

A GPS survey of the east side of the 241-S/SX/SY Tank Farm complex resulted in an additional 1.6 acres of CA/SCA which had not been reported in previous reports. 
Tabie 3. Outdoor Contamination Status 1991 through 1997

[approximate surface area in hectares (acres)]

\begin{tabular}{|c|c|c|c|c|c|c|c|}
\hline Hanford Site Area & 1991 & 1992 & 1993 & 1994 & 1995 & $1996^{\circ}$ & 1997 \\
\hline 100 Areas & $65(160)$ & $65(160)$ & $65(160)$ & $63(155)$ & $52(129)$ & $47(116)$ & $47(116)$ \\
\hline 200 Areas & $157(389)$ & $133(329)$ & $129(318)$ & $105(261)$ & $92(228)$ & $99(245)$ & $95(235)$ \\
\hline 300 Areas & $18(45)$ & $18(45)$ & $18(45)$ & $21(52)$ & $21(52)$ & $20(49)$ & $20(49)$ \\
\hline $600 \&$ BC Control Areas & $1,465(3,620)$ & $1,060(2,620)$ & $1,063(2,627)$ & $1,063(2,627)$ & $1,063(2,627)$ & $3,850(9,513)$ & $3,850(9,923)$ \\
\hline Totals & $1,705(4,214)$ & $1,276(3,154)$ & $1,275(3,150)$ & $1,320(3,261)$ & $1,275(3,150)$ & $4,016(9,923)$ & $4,012(9,913)$ \\
\hline
\end{tabular}

- There are some discrepancies as to the total acreage reported and areas remediated. This is due to the gained accuracy in measurement from the exclusive use of GPS equipment for the measurement of the contaminated surface areas.

${ }^{b}$ The large increase in $600 \& \mathrm{BC}$ Control Areas is due to increased acreage posted around the $\mathrm{BC}$ Control Area. 


\section{DISTRIBUTION}

\section{Number of Copies}

\section{ONSITE}

21

\section{RUST FEDERAL SERVICES NORTHWEST}
J. J. Dorian
$\mathrm{HI}-13$
R. F. Giddings
G6-82
A. R. Johnson
$\mathrm{HI}-13$
B. M. Markes (5)
S. M. Mckinney (12)
$\mathrm{H} 1-13$
R. C. Roos

6

\section{U.S. DEPARTMENT OF ENERGY - Richland}
G. M. Bel1
C. R. Briggs
S. E. Clarke
J. B. HaTT
P. M. Pak
D. C. Ward

A5-52

A5-55

A5-15

A5-15

HO- 12

A5- 15

BECHTEL HANFORD, INC.

18
A. I. Davis
L. A. Dietz
R. G. Egge
J. R. Freeman-Pollard (2)
W. M. Hayward
J. E. Hodgson
R. A. Hughes
W. L. Osborne
T. L. Lafreniere
L. A. Mihalik
G. B. Mitchem
J. E. Parsons
W. H. Price
K. A. Smith
C. D. Wade
C. R. Webb
J. P. Zoric

$\times 2-17$

HO-20

T7-05

H9-12

T7-05

T7-12

HO-16

T7-05

$\times 0-23$

H9-01

$\mathrm{HO}-17$

$\times 0-23$

$\mathrm{HO}-18$

$\times 7-75$

T7-15

H9-10

$\times 5-57$ 


\section{DISTRIBUTION (continued)}

\section{Number of Copies}

3

B\&W HANFORD COMPANY
S. E. Killoy
S4-66
D. J. McBride
T5-54
R. J. Thomas
T4-20

3

DE\&S HANFORD, INC.

D. L. Chase

$\times 3-85$

M. Kaviani

$\times 3-60$

D. J. Watson

$\times 3-79$

2

DYNCORP

H. A. Besel

$T 1-27$

R. A. Schieffer

T1-27

FLUOR DANIEL HANFORD, INC.

3
J. A. Bates
H6-23
D. P. Ellingson
$\mathrm{T} 1-27$
R. L. Watts
G1-17

FLUOR DANIEL NORTHWEST

1

P. I. Thakkar

G3-08

LOCKHEED MARTIN HANFORD CORP.

9

D. Alison

S5-03

J. M. Barnett

S. L. Bump

T4-08

C. L. Caldwe 11

L5-65

D. A. De Lucchi

S5-07

M. L. Dexter

T4-08

R. E. Elder

$\mathrm{R} 1-51$

R. K. P'Pool

S7-07

0 . L. Rasmussen

S5-03

R1-51

2

LOCKHEED MARTIN SERVICES

Document Process Center

A3-94

Central Files

A3-88 


\section{DISTRIBUTION (continued)}

Number of Copies

2

PACIFIC NORTHWEST LABORATORY
R. L. Dirkes (2)
$\mathrm{K} 6-75$

RUST FEDERAL SERVICES OF HANFORD, INC.

5
B. J. Broomfield
T3-04
L. P. Diediker
H6-36
D. L. Mitche11
H6-29
R. D. Pjerce
T3-04
G. C. Triner
T3-05 